Mеталлофиз. новейшие технол. / Metallofiz. Noveishie Tekhnol. (c) 2018 ИМФ (Институт металлофизики 2018, т. 40, № 2, сc. 201-218 / DOI: 10.15407/mfint.40.02.0201 им. Г. В. Курдюмова НАН Украины) Оттиски доступны непосредственно от издателя

Фотокопирование разрешено только

Напечатано в Украине.

в соответствии с лицензией

PACSnumbers: 61.72.Hh, 61.72.Yx, 62.20.M-, 62.40.+i, 68.35.Dv, 71.20.Be, 76.30.-v

\title{
Mechanism of Embrittlement of Metals by Surface-Active Elements
}

\author{
S. M. Teus, B. D. Shanina*, A. A. Konchits*, G. S. Mogilny, \\ and V.G. Gavriljuk \\ G.V.Kurdyumov Institute for Metal Physics, N.A.S. of Ukraine, \\ 36 Academician Vernadsky Blvd., \\ UA-03142 Kyiv, Ukraine \\ "V. E. Lashkaryov Institute of Semiconductor Physics, \\ 41 Nauky Ave., \\ UA-03028 Kyiv, Ukraine
}

The nature of mechanical degradation of metals caused by surface-active elements is studied based on the effects of iodine and gallium in austenitic steels and using ab initio calculations and experimental measurements of electronic structure, X-ray diffraction, mechanical spectroscopy, and mechanical tests. A significant increase in the density of electron states at the Fermi level for iodine in f.c.c. iron is shown that is in consistent with the measurements of the increased concentration of free electrons caused by iodine in austenitic steels. Consequently, the increase in mobility of dislocations by iodine and gallium in austenitic steels is revealed. The localization of the enhanced plastic deformation is discussed as a condition for brittleness. The obtained results are at variance with the widely spread opinion about the determining role of surface energy in a liquid-metal brittleness and, instead, are interpreted based on the correlation between atomic interactions and dislocation properties. Applicability of the available HELP and AIDE hypotheses is discussed.

Key words: f.c.c. iron, austenitic steel, surfactants, electronic structure, dislocations, mechanical properties.

Природу механічної деградації металів, яку спричинено дією поверхнево-

Corresponding author: Valentin Gennadievich Gavriljuk

E-mail: gavr@imp.kiev.ua

Citation: S. M. Teus, B. D. Shanina, A. A. Konchits, G. S. Mogilny, and

V. G. Gavriljuk, Mechanism of Embrittlement of Metals by Surface-Active Elements, Metallofiz. Noveishie Tekhnol., 40, No. 2: 201-218 (2018),

DOI: $10.15407 /$ mfint.40.02.0201. 
активних елементів, було досліджено, виходячи із впливу Йоду та Галію на аустенітні сталі та використовуючи ab initio-розрахунки й експериментальні дослідження електронної структури, рентгенівську дифракцію, механічну спектроскопію та механічні випробування. Показано істотне підвищення густини електронних станів на рівні Фермі у випадку Йоду в ГЦК-залізі, що узгоджується з вимірюваннями, в яких було зафіксовано підвищену концентрацію вільних електронів, яку спричинено Йодом в аустенітних сталях. Як наслідок, встановлено підвищення мобільности дислокацій, спричинене Йодом і Галієм в аустенітних сталях. Обговорюється роль локалізації підвищеної пластичної деформації в якості умови крихкости. Одержані результати суперечать розповсюдженим твердженням про визначальну роль поверхневої енергії в рідкометалевому окрихченні і замість цього інтерпретуються, виходячи з кореляції між атомними взаємодіями та дислокаційними властивостями. Обговорюється коректність гіпотез HELP та AIDE.

Ключові слова: ГЦК-залізо, аустенітна сталь, сурфактанти, електронна структура, дислокації, механічні властивості.

Природа механической деградации металлов, обусловленной поверхностно-активными элементами, была изучена, основываясь на влиянии йода и галлия на аустенитные стали и используя ab initio-расчёты и экспериментальные исследования электронной структуры, рентгеновскую дифракцию, механическую спектроскопию и механические испытания. Показано существенное повышение плотности электронных состояний на уровне Ферми в случае йода в ГЦК-железе, что согласуется с измерениями, в которых была зафиксирована повышенная концентрация свободных электронов, вызванная йодом в аустенитных сталях. Как следствие, установлено повышение мобильности дислокаций, вызванное йодом и галлием в аустенитных сталях. Обсуждается роль локализации повышенной пластической деформации в качестве условия хрупкости. Полученные результаты противоречат широко распространённому мнению об определяющей роли поверхностной энергии в жидкометаллической хрупкости и, вместо этого, интерпретируются, основываясь на корреляции между атомными взаимодействиями и дислокационными свойствами. Обсуждается применимость гипотез HELP и AIDE.

Ключевые слова: ГЦК-железо, аустенитная сталь, сурфактанты, электронная структура, дислокации, механические свойства.

(Received November 9, 2017)

\section{INTRODUCTION}

Phenomenon of liquid metal embrittlement (LME) is known since 1874 (see, e.g., [1]). Later on, it has been shown that solid metal films can also cause brittle fracture, SME (e.g., [2]). The first physical interpretation of surface-active elements, surfactants in the following, on mechanical properties of solids has been proposed in 1928 [3] and desig- 
nated as Rehbinder's effect. As formulated in his short communication at the VI Congress of Russian Physicists, Rehbinder declared 'the effect of the surface energy of a crystal (calcite, rock salt, gypsum, or mica) on its mechanical and other properties by decreasing the surface tension of crystal faces via the introduction of surfactants which form Gibbs-Langmuir layers at the interfaces'. This idea has been resulted in the extensive practical applications, e.g., for easing the cutting of tough materials due to their local embrittlement. Starting from the fifties, important practical consequences were concerned with the development of nuclear reactors using the lead-bismuth eutectic as a coolant, where the liquid-metal embrittlement, LME, creates a serious problem (see, e.g., [4]).

A number of original research papers, review articles and monographies are concerned with this not ordinary phenomenon, e.g., [5-10]. Nevertheless, an operating mechanism remains so far debatable. The surfactants-induced decrease in the strength constitutes a topic of many studies treating Rehbinder's concept in terms of the Griffith's relation between the surface free energy per unit area of the crack, $\gamma$, and the fracture strength $\sigma_{G r}=(\gamma E /(\pi c))^{1 / 2}$, where $E$ is the Young modulus and $c$ is the length of the initial crack formed under applied stress.

The application of this formula suggests a decrease in strength due to adsorption of surfactants on the crack surface, which decreases the surface energy. This rather simple thermodynamic interpretation was, probably, first time proposed in [11] and remains to be discussed (see, e.g., $[12-14])$.

A mechanism of surfactant atoms penetration into the metal is being preferentially related with the grain boundaries. For example, liquidchannel grain boundary structures in ceramic materials were analysed in [15], whereas a 'self-indentation-internal-solution' mechanism has been proposed in [16], according to which the liquid metal causes grain boundary 'grooving', which removes the solid material from the bulk and dissolves it in the liquid channel.

A role of the crystal structure is also considered important for LME appearance, e.g., the transcrystalline LME fracture occurs in martensitic steels and binary ferrous alloys [17] and it is intercrystalline in f.c.c. polycrystalline metals [18].

As a mechanism for LME, the adsorption-reduced cohesion caused by the surfactant atoms within the crack tip was proposed by Kamdar in $[19,20]$ in consistency with Rehbinder's effect. For substantiation of breaking the atomic bonds, this mechanism suggests a criterion of a critical relation between normal and shear stresses, which was earlier analysed in [21]. In these terms, the transcrystalline fracture can be interpreted as a result of prevailing normal stresses. Nevertheless, at variance with this idea, LME was also found in the amorphous ironbased materials, e.g., [22, 23], where both deformation and fracture 
proceed only through the shear processes.

Important for the clarification of operative mechanisms was the observation that embrittlement by surfactants is accompanied by a local increase of plasticity (see, e.g., [24-26]). In other words, the locally enhanced plastic deformation precedes the macrobrittle fracture. In the attempt to interpret this unusual behaviour, the local disintegration of solids resulted in colloidal disperse systems was proposed in [5, 6]. Such an approach was complemented by the ideas about liquid channels $[15,16]$ and corresponding grain boundary phase transitions [27, 28].

However, such an interpretation of preceded plastic deformation is seriously discredited by a striking similarity between LME and hydrogen embrittlement, HE, which has been remarked already in the first observations of LME [1]. A significant localized plastic flow always precedes the hydrogen-caused brittle fracture of metals.

Systematic comparative studies of LME and HE were carried out by Lynch (see, e.g., [29]). Based on these studies and using the above mentioned idea of surfactant atoms adsorption within the crack tip, he has proposed the adsorption-induced localized-slip process to be responsible for both the LME and HE phenomena [30] and, correspondingly, developed the hypothesis of 'adsorption-induced dislocation emission', AIDE, [30, 31]. Its essence amounts to the facilitated nucleation and emission of dislocations due to adsorption of hydrogen or surfactant atoms at the internal surface of the crack tips. Once nucleated, the dislocations can readily move away from the crack tip under applied stress.

Along with AIDE hypothesis, the hydrogen embrittlement of metals is described by the widespread hypothesis of hydrogen-enhanced localized plasticity, HELP. The analysis of both hypotheses is presented, e.g. in the review articles [32, 33].

A common feature for the variety of the above-mentioned studies is that the analysis of LME and SME ignores the change in the electron structure caused by surfactants, which should affect both atomic interactions and properties of dislocations. The aim of this paper is to compensate this gap.

\section{CALCULATIONS AND EXPERIMENTAL}

Iodine and gallium have been chosen as surfactants because of possibility to carry out the experiments at ambient temperature. Their role in mechanical degradation of metals is well known, e.g. [13, 34]. Moreover, iodine is widely used for public demonstration of LME, e.g., extrabrittle fracture of zinc crystals. The $\mathrm{CrNi}$ austenitic steels doped by surfactants were investigated using theoretical and experimental studies of the electron and crystal structures followed by the experiments on dislocation properties and mechanical behaviour. 
$A b$ initio calculations of the effect of surfactants on the electron structure have been performed using iodine in the $\gamma$-iron. The f.c.c. iron cluster (cell) of 32 iron atoms and that of 31 iron +1 iodine ones were calculated. The total potential, the electron density, and the total energy per cell have been calculated using the computational program package Wien2k developed by the European scientific group [35]. These calculations are based on the Kohn-Hohenberg-Sham density functional theory (DFT) [36, 37].

The initial electron density for solving the Kohn-Sham equations was taken in the local spin density approximation (LSDA) [38]. A procedure for solving these equations is the full-potential-linearizedaugmented plane wave method (FLAPW). The calculation of the exchange-correlation potential is carried out using the generalized gradient approximation in the parameters of Perdew, Burke, and Ernzernhoff [39], where the gradient terms of electron density are added to the exchange-correlation energy and its potential. The integration over the Brillouin zone is carried out using the modified tetrahedron method [40] over the $15 \times 15 \times 15$ points in k-mesh for $\mathrm{Fe}-\mathrm{I}$ system. The wave functions, the charge densities, and the potential were expanded with $L \leq 10$ spherical harmonics inside each 'muffin-tin' radius, RMT, of 2.16 a.u. and 2.39 a.u. for Fe and I atoms, respectively.

A procedure for the full relaxation has been carried out, which consists of volume relaxation, shape relaxation and the relaxation of internal atomic positions. The equilibrium state and, consequently, equilibrium lattice parameters have been obtained.

All calculations were performed in the full relativistic approach with the spin polarized electron states at temperature $T=0 \mathrm{~K}$. Selfconsistency was achieved when the root-mean square distances between the $j$ and $(j-1)$ steps of the iteration procedure for the total charges and spin densities were smaller than $1.0 \cdot 10^{-4}$.

Using the pure iron, chromium, nickel, and manganese, four austenitic steels Cr15Ni15, Cr15Ni20, Cr25Ni20, and Cr15Ni25Mn15 (see Table 1) have been melted in vacuum, as ingots of $175 \mathrm{~g}$ in the mass, followed by homogenization at $1150^{\circ} \mathrm{C}$ for 24 hours.

TABLE 1. Chemical compositions*.

\begin{tabular}{c|c|c|c|c}
\hline Steel & $\mathrm{Cr}$ & $\mathrm{Ni}$ & $\mathrm{Mn}$ & $\mathrm{Fe}$ \\
\hline Cr15Ni15 & 15.4 & 14.4 & - & Balance \\
\hline Cr15Ni20 & 16.0 & 19.7 & - & Balance \\
\hline Cr15Ni25Mn15 & 15.3 & 25.6 & 14.8 & Balance \\
\hline Cr25Ni20 & 25.2 & 20.2 & - & Balance \\
\hline
\end{tabular}

"Non-purposefully added elements were not determined. 
The foils of $20 \mu \mathrm{m}$ and $0.55 \mathrm{~mm}$ in thickness were prepared by rolling for the measurements using electron spin resonance, ESR, and Xray diffraction, respectively. Wire specimens of $0.6 \mathrm{~mm}$ in diameter were obtained by cold drawing with intermediate annealing for mechanical spectroscopy. For all specimens, the final annealing was performed at $1050^{\circ} \mathrm{C}$ for $30 \mathrm{~min}$.

The electron paramagnetic resonance spectrometer in the X-band of the microwave field was used for experimental studies of the electron structure. The ESR spectra were obtained at the optimum experimental conditions and recorded as derivative $d P / d H$ from the absorbed microwave power $P$ on the applied magnetic field $H$. Thereafter, all parameters were reduced to the same conditions: modulation field amplitude $H_{m}=0.125 \mathrm{G}$, amplifying coefficient $K=10^{4}$, and microwave power $P=-35 \mathrm{~dB}$. A piece of the $\mathrm{MgO}: \mathrm{Cr}^{3+}$ compound with the number of spins $1.1 \cdot 10^{16}$ served as a reference sample.

The analysis of experimental spectra has been carried out based on the theory of ESR for free electrons [41] and using a technique developed in our previous studies [42, 43].

The X-ray diffraction was used for measurements of iodine and gallium effects on the lattice parameters of austenitic steels. The diffraction patterns were obtained using Huber diffractometer with twocircle goniometer and $\mathrm{Cu} K_{\alpha}$ radiation under operating voltage of 30 $\mathrm{kV}$. A graphite monochromator was used at the secondary beam to decrease the noise level. A computer program controlled the angular movement of both goniometer and counter. The error in determination of the angle position did not exceed $0.001^{\circ}$. The fitting of diffraction reflections was carried out using the program ProFit taking into account the $\mathrm{Cu} K_{\alpha}$ doublet.

Measurements of the amplitude-dependent internal friction for studies of dislocation properties were carried out within the strain amplitude of $0.5 \cdot 10^{-6}$ to $5 \cdot 10^{-4}$ using an automated inverted pendulum operating at temperatures from 80 to $580 \mathrm{~K}$ and frequencies of about 1 $\mathrm{Hz}$.

Mechanical tests were performed at room temperature using a machine H5-K-T of Hounsfield Company, UK, with the loading rate of $1.7 \cdot 10^{-3} \mathrm{~s}^{-1}$.

To saturate the samples with iodine, they were immersed at room temperature into a standard 5\% iodine solution in the ethanol for 72 hours. Before the installation into the experimental device, EPR spectrometer, internal friction pendulum or mechanical test machine, the samples were cleaned with a soft paper.

In the course of processing with gallium, the sample was kept in the gallium bath at 35,40 or $100^{\circ} \mathrm{C}$ for 5 to 68 hours. After this procedure, the samples were cleaned with a soft paper to remove the gallium drops from the sample surface. 


\section{RESULTS}

\subsection{Electron Structure: Calculations}

The paramagnetic state of f.c.c. iron, $\gamma$-Fe, is rather complicated for theoretical calculations, because it corresponds to a disordered spin orientation and is not really nonmagnetic. As mentioned in [44], the ground state of $\gamma-\mathrm{Fe}$ is located at a crossing point of ferromagnetic (FM) and antiferromagnetic (AFM) magnetic states, which substantially depends on the atomic volume. According to neutron diffraction measurements, magnetic moments in the $\gamma$-Fe form the spin density waves. The first-principle calculations performed using a noncollinear spin magnetism theory confirm also that the ground state of the $\gamma$-Fe is a spin spiral state $[45,46]$. At a slight increase in the lattice parameter, f.c.c. Fe becomes ferromagnetic. By using the collinear magnetic moments within the DFT theory [47], it was shown that the spin spiral state could be well described by the double layer antiferromagnetic (AFMD) configuration.

The theoretical description of FM states reveals two possible magnetic configurations: low-spin ferromagnetic (LS-FM) and high spin ferromagnetic (HS-FM). In consistency with the arguments mentioned in [48], we have chosen the HS-FM state to simulate the f.c.c. $\gamma$-Fe. The reasons for that are the following: (i) the HS-FM state of the f.c.c. iron is observed experimentally [49-51]; (ii) the HS-FM state was used to explain the experimentally observed anti-invar effect in f.c.c. Fe [48, 49], and (iii) if properties predicted from the first-principle calculations are compared with the experimental ones obtained at finite temperatures, the HS-FM state seems to be the most correct for such analysis.

Figure 1 shows the total density of states (DOS) per cell for the spin up and spin down electron states. Numerical results of calculation are presented in Table 2.

Iodine in the iron crystal lattice causes appearance of the bonding states at the bottom of the metallic $d$-band and increases the total density of states at the Fermi level. The analysis of partial contributions to the total DOS shows that the $\mathrm{Fe}-\mathrm{I}$ atomic bonding is mainly created by the electrons of the Fe3d and I5p orbitals. At the same time, the insertion of iodine atoms into the iron crystal lattice strikingly changes the contribution to the DOS at the Fermi level from $3 d$ iron electrons. It constitutes 0.88 states $/(\mathrm{eV}$-atom $)$ in the pure f.c.c. iron and 0.98 states/(eV.atom) in the $\mathrm{Fe}-\mathrm{I}$ system.

This result is consistent with the data of spatial distribution of electron density in its $2 D$ projection in Fig. 2, which has been constructed using the XCrysden program developed in [52].

The valence states were cut off from the core and semi-core (accord- 


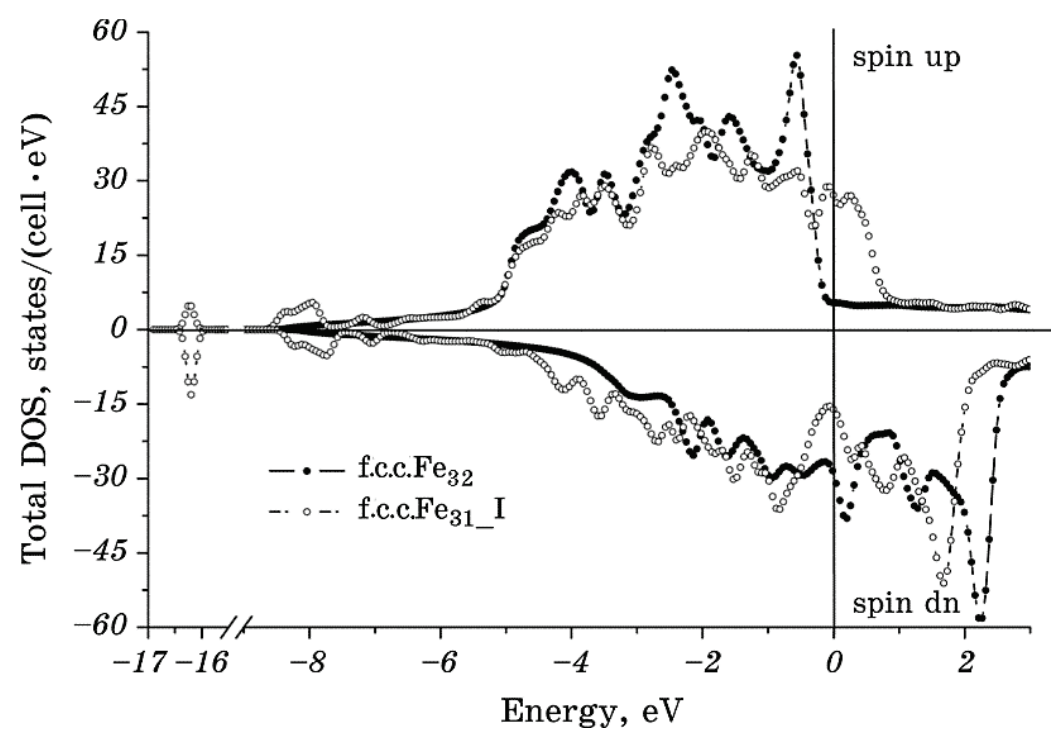

Fig. 1. Effect of iodine on the total density of electron states per cell in the $\gamma$ iron crystal lattice. 'Cell' means the calculated clusters of $32 \mathrm{Fe}$ atoms and 31 Fe atoms + 1 I atom, respectively.

TABLE 2. Calculation results on the total density of states (DOS) for spin up and spin down states in the iron and iron-doped iodine structures.

\begin{tabular}{c|c|c|c}
\hline Structure & $\begin{array}{c}\text { DOS (up states), } \\
\text { states/(cell.eV) }\end{array}$ & $\begin{array}{c}\text { DOS (down states), } \\
\text { states/(cell.eV) }\end{array}$ & $\begin{array}{c}\text { Total DOS } \\
\text { (up + down states), } \\
\text { states/(cell.eV) }\end{array}$ \\
\hline f.c.c. Fe & 5.40 & 28.71 & 34.11 \\
f.c.c. $\mathrm{Fe}+\mathrm{I}$ & 27.24 & 16.05 & 43.29 \\
\hline
\end{tabular}

ing to DFT) ones, and the plane (001) was chosen for presentation. As seen, the substitution of an iron atom for the iodine one in the iron crystal lattice causes a distortion of electron density at the neighbouring iron atoms and increases the electron density in the interstitial area. The latter suggests the enhancement of metallic character of interatomic bonds.

\subsection{X-Ray Diffraction}

A shift of the reflections $(111)_{\gamma}$ and $(200)_{\gamma}$ by $0.04^{\circ}$ towards higher angles occurs after holding of steel $\mathrm{Cr} 25 \mathrm{Ni} 20$ in the iodine (Fig. $3, a$ ). It is by 40 times higher than the measurements precision of $0.001^{\circ}$, i.e., the lattice contraction occurs due to iodine. The estimated lattice pa- 

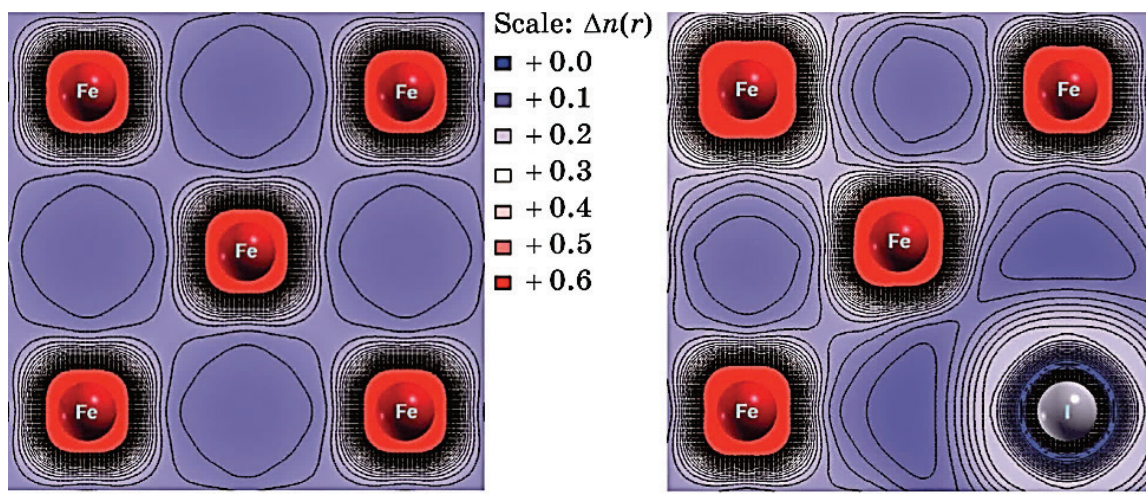

Fig. 2. $2 D$ spatial distribution of valence electrons, $\Delta n(r)$, in the calculated clusters: 32 Fe atoms, 31 Fe atoms + 1 I atom.

rameters are equal to $0.3595 \pm 0.0001 \mathrm{~nm}$ before and $0.3591 \pm 0.0002$ $\mathrm{nm}$ after holding in the iodine solution. A much smaller effect, nearly within the frame of the experimental error is obtained in case of gallium (Fig. 3, $b$ ). This difference in the lattice response can be tentatively attributed to a weaker penetration of gallium into the $\gamma$-iron crystal lattice.

The iodine- and gallium-caused shift of reflections is shown in the inserts with the peaks positions from the $K_{\alpha}$ doublet before, $\gamma_{1}$, and after, $\gamma_{2}$, holding in the surfactants.

After holding at $35^{\circ} \mathrm{C}$, beside the reflections of the austenitic steel, the diffraction pattern contains those of gallium. These reflections disappear if holding occurred at $100^{\circ} \mathrm{C}$, i.e., far from the gallium crystallization temperature.

Remarkably, the holding in gallium changes the intensity of reflections (111) $)_{\gamma}$ and (200) $)_{\gamma}$ in the opposite directions. Some hint for the interpretation can be derived from the calculations performed by Legris et al. [12] who obtained different adsorption energy of surfactant atoms for different crystallographic orientations of the iron surface.

\subsection{Electronic Structure: Experiment}

As example, the spectra of electron spin resonance of austenitic steel Cr15Ni15 measured at $77 \mathrm{~K}$ before and after holding in the iodine solution are presented in Fig. 4. They were recorded as derivatives from the absorbed microwave power $P$ on the applied magnetic field $H$. The obtained data of the concentration of free electrons are presented in Table 3. One can see that the iodine increases the concentration of free electrons in the austenitic steels in consistency with the increase in the density of electron states at the Fermi level of f.c.c. iron, which was 

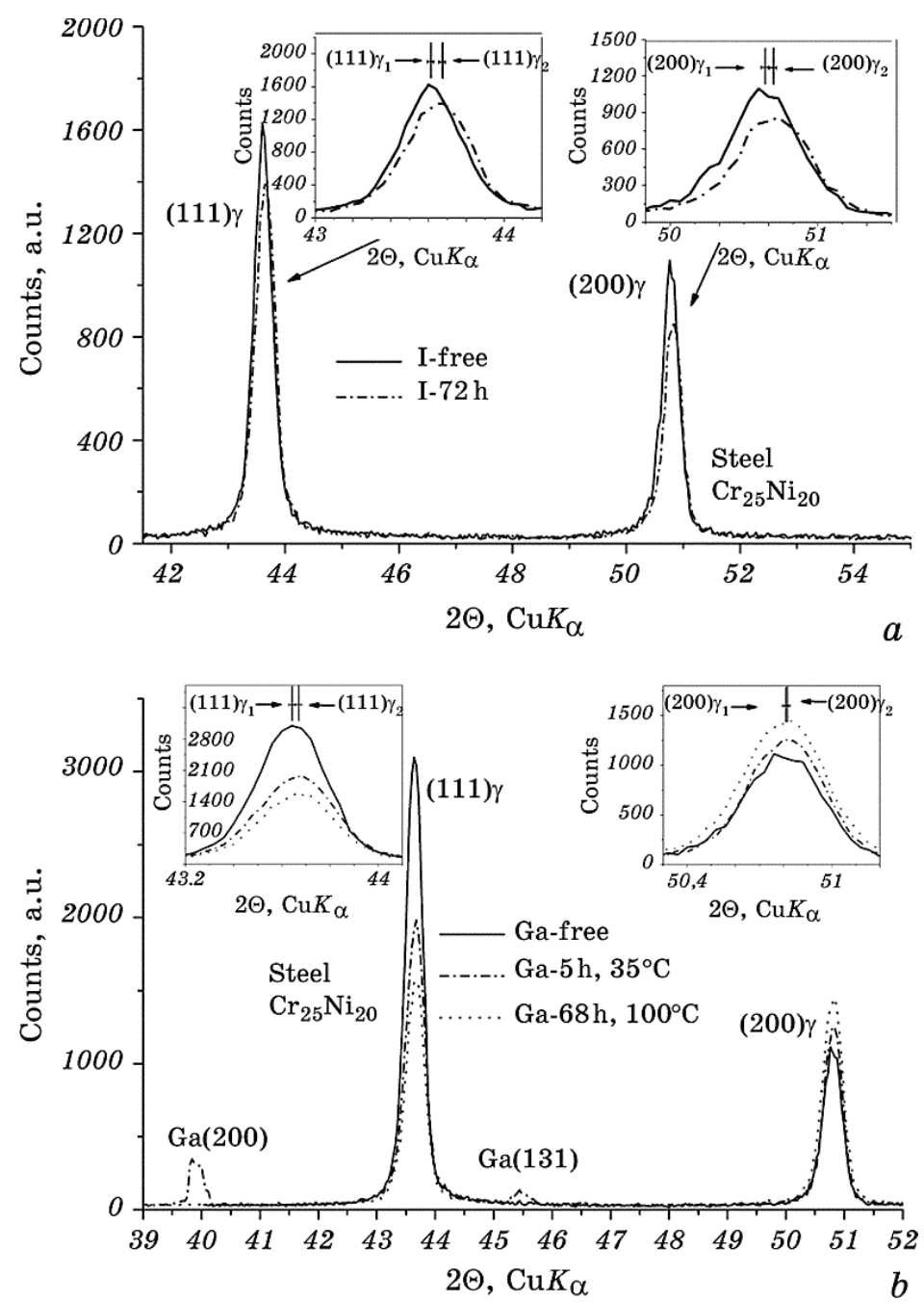

Fig. 3. X-ray diffraction from steel Cr25Ni20 before and after immersion into $5 \%$ iodine solution in the ethanol for 72 hours $(a)$ and gallium at 35 and $100^{\circ} \mathrm{C}$ for 5 and 68 hours $(b)$, respectively.

presented in Fig. 1. It is worth noting that the ESR data are obtained from the samples of $20 \mu \mathrm{m}$ in thickness, i.e., this is not the surface effect.

\subsection{Mobility of Dislocations}

The effect of iodine and gallium on dislocation properties of austenitic steels was studied using mechanical spectroscopy. In the absence of re- 


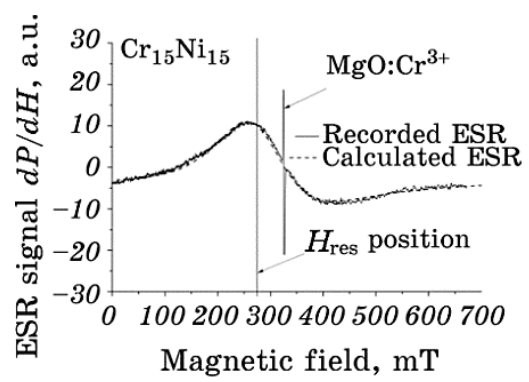

$a$

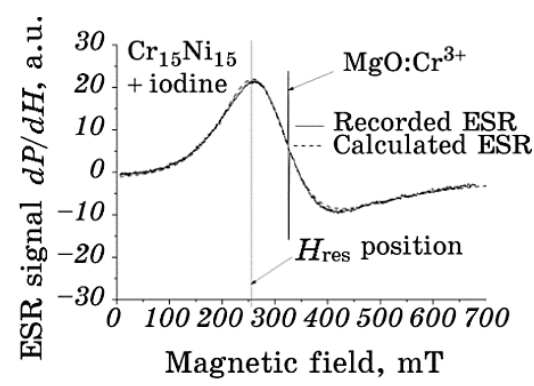

$b$

Fig. 4. Electron spin resonance spectra of austenitic steel Cr15Ni15: iodinefree $(a)$, after holding for 72 hours in the iodine solution at RT $(b)$. A narrow intensive line is the ESR signal of a peace of the reference sample $\mathrm{MgO}: \mathrm{Cr}^{3+}$ with the number of spins $1.1 \cdot 10^{16}$. Spectra are measured at $77 \mathrm{~K}$.

laxation processes, the internal friction background is controlled by vibrations of dislocations $[53,54]$. Its value is the higher the larger the area crossed by vibrating dislocations. Therefore, under condition of the constant frequency of the induced vibrations, it is proportional to the velocity of dislocations.

The observed increase in the concentration of free electrons by the surfactants suggests a weakening of interatomic bonds. This should result in a decrease of the shear modulus $\mu$ and, correspondingly, decrease the specific energy of dislocations, i.e. their line tension $\Gamma \approx$ $\approx\left[\mu b^{2} /(4 \pi)\right] / \log (\Re /(5 b))$, where $\Re$ is a radius of dislocation curvature.

The strain-dependent internal friction in steels $\mathrm{Cr} 15 \mathrm{Ni} 25$ and Cr25Ni20 doped by iodine and gallium, respectively, is presented in Fig. 5, $a, b$. Both surfactants increase the internal friction background and the slope $\Delta Q^{-1} / \Delta \varepsilon$, which evidences the increase of dislocation velocity in consistency with the increase in the concentration of free electrons.

TABLE 3. Integral intensities $I / I_{\text {ref }}$ of ESR signals in relation to those from the reference sample and concentrations of free electrons $N_{e}$ in austenitic steels before (numerator) and after (denominator) holding in the iodine solution.

\begin{tabular}{c|c|c}
\hline Steel & $I / I_{\text {ref }}, 10^{4}$ & $N_{e}, \mathrm{~cm}^{-3}, 10^{23}$ \\
\hline Cr15Ni15 & $\frac{4.01}{6.32}$ & $\frac{1.7}{2.67}$ \\
Cr15Ni20 & $\frac{2.88}{7.02}$ & $\frac{1.4}{4.29}$ \\
\hline
\end{tabular}




\subsection{Mechanical Tests}

Tensile tests of studied austenitic steels have shown that, in spite of increase of dislocation mobility, both iodine and gallium cause embrittlement (Fig. 6).

As it is also usually, the case of hydrogen embrittlement in austenitic steels, the local softening of the crystal lattice does not decrease the yield strength of tested samples. This feature is clearly seen in case of iodine.

\section{DISCUSSION}

\subsection{Atomic Interactions, Surfactants Distribution and Mobility of Dislocations}

The iodine-caused increase in the density of electron states at the Fermi level derived from the ab initio calculations (see Figs. 1 and 2) is confirmed by the measurements of the electron spin resonance demonstrating the increase in the concentration of free electrons (Fig. 4). It is worth noting that the ESR data are related to the bulk of the samples, not to the surface, i.e., the obtained result cannot be explained just by a decrease in the surface energy, which is traditionally used for interpretation of the surfactants effect on mechanical properties.

The iodine- and gallium-caused decrease in the lattice parameter, as shown in Fig. 3, is consistent with the usually expected negative deviation from the Vegard rule for the lattice parameters of the solid solutions. Possibly, because of the different iodine and gallium penetration in steel for the experimental time, this effect is more remarkable in

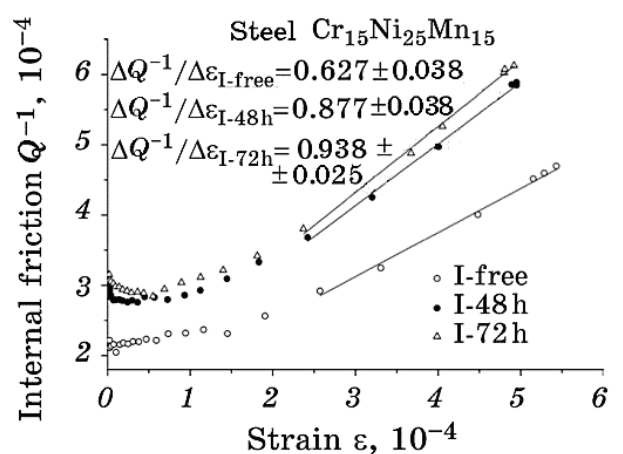

$a$

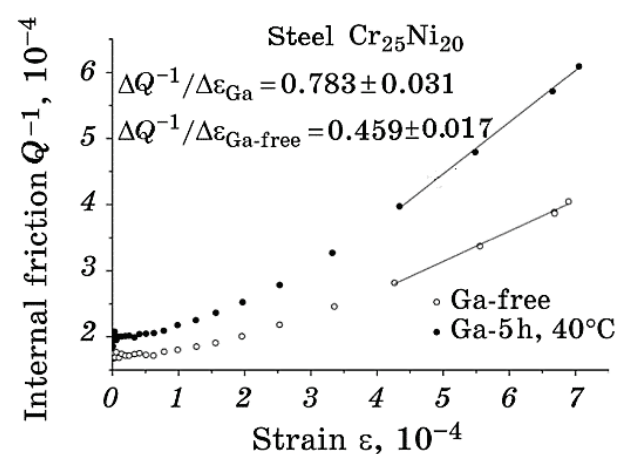

b

Fig. 5. Strain-dependent internal friction in austenitic steels before and after contact with surfactants: iodine, steel Cr15Ni25Mn15 (a), gallium, steel Cr25Ni20 (b). 


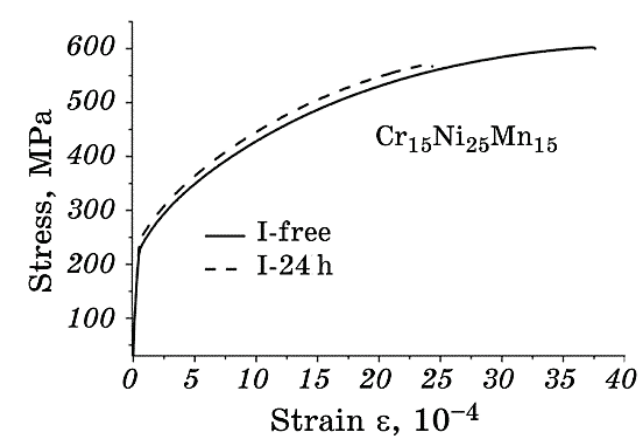

$a$

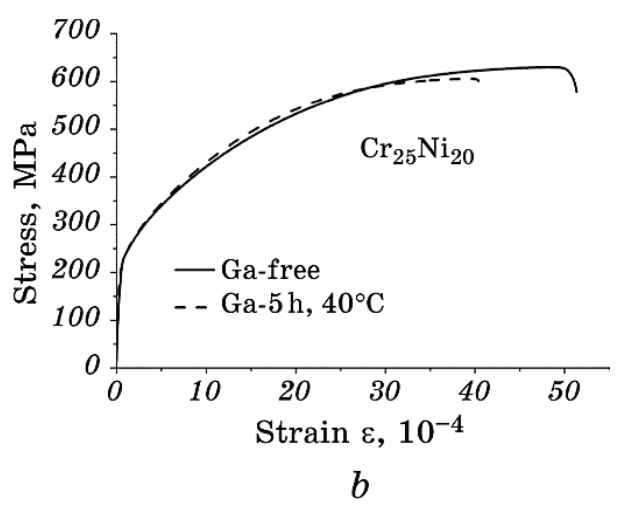

Fig. 6. Engineering stress-strain curves of austenitic steels Cr15Ni25Mn15 (a) and $\mathrm{Cr} 25 \mathrm{Ni} 20(b)$ before and after holding in iodine and gallium, respectively.

case of iodine and occurs to a smaller extent for gallium.

A feature of the gallium effect is a decrease in the intensity of (111) reflection and the opposite tendency for the $(200)_{\gamma}$ one (Fig. 3, b). This abnormal ratio of intensities is obviously a sign of the crystallographic texture, which can be caused by a selective location of gallium atoms along the (111) $)_{\gamma}$ atomic planes, which decreases the intensity of (111) reflections in the X-ray diffraction pattern. In other words, gallium preferentially covers the surface of grains with a favourable orientation of their (111) $\gamma$ plane in relation to the surface. The accompanying increase in the intensity of the (200) $)_{\gamma}$ peak needs a more thorough additional analysis.

At the same time, a larger shift of the (111) reflection to smaller angles in comparison with the (200), one means that such a selectivity in gallium atom location exists deeply under surface. In other words, the gallium atoms prefer the (111) $\gamma$ atomic planes for adsorption in the bulk of f.c.c. iron solid solution, not only at the surface.

The next remarkable effect of iodine and gallium is the increase in the velocity of dislocations, which evidences the enhancement of dislocation slip (see Fig. 5). A similar behaviour was observed in hydrogencontaining austenitic steels (see, e.g., [55]).

It is hardly possible that dislocation slip is accompanied by migration of surfactant atoms as it occurs in case for hydrogen as a condition for the change of dislocation properties. Rather, the facilitated slip is localized in some limited areas where the surfactant atoms are preferentially present.

\subsection{Hypotheses for Surfactants-Caused Embrittlement}

A similarity of two phenomena, LME and HE, has stimulated interpre- 
tation of surfactants-caused embrittlement in terms of hypotheses developed for hydrogen degradation of metals. As mentioned above, the essence of AIDE hypothesis in relation to both HE and LME is that, be adsorbed at the internal surface of crack tips, hydrogen and surfactants atoms ease the nucleation of dislocations and their emission. Three statements in this hypothesis are remarkable: (i) a critical is the stage of dislocation nucleation; (ii) hydrogen or surfactants atoms located in the solid solution are not responsible for embrittlement; (ii) the enhanced mobility of dislocations does not play any substantial role in the embrittlement.

The following remarks can be made in relation to the ideas underlined in the AIDE theory. First, while starting from nucleation and emission of dislocations from the crack tip, this hypothesis ignores the role of hydrogen or surfactants in the stage of cracks origin under applied stress. Pre-existing cracks can occur and not occur before hydrogen charging or contact with surfactants. In case of hydrogen in metals, they are really formed in the course of cathodic charging because of a sharp hydrogen concentration profile and corresponding stresses. However, it is not the case for gaseous hydrogenation.

Second point concerns the crack growth. According to [32], it occurs due to emission of dislocations from the crack tip along with formation of nanovoids. If so, the dislocation half-loops and a definite gradient of dislocation density should be observed under fracture surface. However, as shown in [56] for hydrogen-charged austenitic steels, no halfloops occur beneath the fracture surface and the uniform dislocation structure extends to the depth of $1500 \mathrm{~nm}$ from the fracture surface.

It is worth noting that, similarly, the high density of dislocations is observed under surface fracture of high-nitrogen austenitic steels, e.g. [57], where, like hydrogen embrittlement, the quasi-cleavage occurs at low temperatures in spite of the nitrogen-enhanced local plasticity (see about details Ref. [33]).

Third, the hydrogen-caused formation of the voids is not properly substantiated in the AIDE hypothesis. In fact, it does not need any presence of second-phase particles and high stresses for dislocation emission. Along with vacancies emitted due to intersection of screw dislocations, like any other interstitial element in the metal solid solution, hydrogen increases the thermodynamically equilibrium concentration of vacancies, which has been theoretically predicted in [58, 59], and first time observed in the experiments on the hydrides [60] and austenitic steels [61].

These vacancies cannot follow dislocations in the course of plastic flow. They are expected to form nanovoids along the slip planes, which decreases the load bearing area. In case of surfactants-caused brittleness, a possible role of nanovoids has been so far not clearly substantiated. 
In contrast to AIDE, the HELP hypothesis of hydrogen embrittlement is based on the primary role of interaction between hydrogen atoms and dislocations, which was first time presented by Robertson and Birnbaum [62] in their in situ observations of hydrogen-caused increased generation rate and velocity of dislocations in nickel. Later on, Birnbaum and Sofronis have developed a theory within the frame of continuum mechanics, of which the essence is the hydrogen-caused shielding of the interaction between dislocations and elastic stress centres [63]. The further development of this theory was proposed in [64] and a thorough review of theoretical and experimental data can be found in [65].

The electronic approach to HELP phenomenon has been developed in $[33,66,67]$ taking into account the hydrogen-caused increase in the concentration of free electrons and corresponding local decrease in the shear modulus $\mu$, which changes dislocation properties.

The theoretical and experimental data obtained in this study show that, like hydrogen, surfactants in austenitic steels increase the concentration of free electrons in the iron and iron-based alloys.

For this reason, in both cases of hydrogen and surfactants, the following consequences are expected: (i) a decrease of the stress for emission of dislocations $\tau \approx 2 \mu b / L$, where $b$ is the Burgers vector and $L$ is a distance between pinning points; (ii) the enhancement of mobility of dislocations due to a decrease in their specific energy, i.e. line tension $\Gamma \approx\left[\mu b^{2} /(4 \pi)\right] / \log (\Re /(5 b))$, where $\mathfrak{R}$ is the radius of the dislocation curvature; (iii) a decrease in the distance between dislocations in the pileups, $d \approx(\pi \mu b) /[16(1-v) n \tau]$, which assists the nucleation of cracks due to the increase in the number of dislocations $n$, and, correspondingly, the stress at the leading dislocation $\tau_{L}=n \tau$, where $\tau$ is the active shear stress in the slip plane. This decrease in the distances between dislocations was experimentally confirmed in [68] for hydrogen and should facilitate the opening of microcracks.

Thus, the increase in mobility of dislocations eases the plastic deformation. A limited surfactants penetration and their non-homogenous distribution in the solid solution can be a reason for localization of plastic deformation leading to the decrease in plasticity or macrobrittle fracture.

The obtained data also allow mentioning that, like hydrogen embrittlement, LME and SME phenomena are not really the surface effects, and term 'surfactant' is to some extent disputable. Therefore, one can foresee that any chemical element enhancing metallic character of interatomic bonds acts as surfactant if there are conditions for localization of plastic deformation. At the same time, in the absence of plastic flow localization, it should markedly increase plasticity and toughness.

This idea can be illustrated at least by two examples. First, pos- 
sessing a high concentration of free electrons, copper is generally not accepted as surfactant. At the same time, it causes LME, as well as SME, in the artillery gun tubes be present on the projectile to provide a gas seal and to assist its spin up for providing subsequent flight stabilization (see, e.g., [10]). However, copper is successfully used as alloying element in austenitic steels for production of corrosion-resistant wire and ropes where its occurrence substantially eases drawing of steel wire and increases plasticity (e.g., [69]). Second example is concerned with lithium which, be the well-known surface-active element, is successfully used in $\mathrm{Al}-\mathrm{Li}$ alloys for development of the advanced structural materials (see, e.g., [70]). At the same time, due to shortrange and even long-range ordering in the $\mathrm{Al}-\mathrm{Li}$ solid solutions, these alloys are prone to localization of plastic deformation. The ageing leading to precipitation of $\mathrm{Al}_{3} \mathrm{Li}$ and $\mathrm{Al}_{3} \mathrm{X}$ particles is used to diminish the effect of localization of plastic flow.

\section{CONCLUSIONS}

1. The increase in the density of electron states at the Fermi level and corresponding increased concentration of free electrons are responsible for the local enhancement of metallic character of interatomic bonds by iodine in f.c.c. iron and austenitic steels. The same effect is expected for gallium.

2. As consequence, these surfactants enhance mobility of dislocations in austenitic steels.

3. It is supposed that any chemical element enhancing the metallic character of interatomic bonds can play the role of surfactant if the localized plastic deformation occurs because of the limited area of its contact with the metal or due to atomic ordering in the solid solution.

4. The nature of embrittlement of austenitic steels by surfactants can be interpreted within the frame of the electron approach to HELP hypothesis, which has been earlier developed for hydrogen embrittlement.

\section{REFERENCES}

1. W. H. Johnson, Proc. R. Soc. Lond., 23: 168 (1874).

2. J. C. Liynn, W. R. Warke, and P. Gordon, Mat. Sci. Eng., 18: 51 (1975).

3. P. A. Rehbinder, Communications of VI Congress of Russian Physicists (Moscow: OGIZ: 1928), p. 29.

4. B. F. Gromov, Yu. S. Belomitsev, and E. I. Yefimov, Nuclear Eng. Design, 173: 207 (1997).

5. V. I. Lichtman, E. D. Shukin, and P. A. Rehbinder, Physical-Chemical Mechanics of Metals (Moscow: Academy of Sci. USSR: 1962) (in Russian).

6. E. D. Shchukin and P. A. Rehbinder, Selected Studies. Surface Phenomena in 
Disperse Systems. Physical-Chemical Mechanics (Moscow: Nauka: 1979) (in Russian).

7. M. G. Nicolas and C. F. Old, J. Mater. Sci., 14: 1 (1979).

8. A. I. Malkin, Z. M. Polukarova, V. M. Zanozin et al., Environment-Induced Cracking of Materials: Chemistry, Mechanics and Mechanisms (Eds. S. A. Shipilov, R. H. Jones, J.-M. Olive, and R. B. Rebak) (Oxford: Elsevier Science: 2008), p. 497.

9. J.-B. Vogt, I. Serre, A. Verleene, and A. Legris, Environment-Induced Cracking of Materials: Chemistry, Mechanics and Mechanisms (Eds. S. A. Shipilov, R. H. Jones, J.-M. Olive, and R. B. Rebak) (Oxford: Elsevier Science: 2008), p. 481.

10. C. N. Vigilante, S. Bartolucci, J. Izzo, M. Witherell, and S. B. Smith, Mater. Manufact. Processes, 27: 835 (2012).

11. P. A. Rehbinder and E. D. Shchukin, Progr. Surf. Sci., 3: 97 (1972).

12. A. Legris, G. Nicaise, J.-B. Vogt, and J. Foct, J. Nucl. Mater., 301: 70 (2002).

13. D. Gorse, S. Goryachev, and T. Auger, Proc of $3^{\text {rd }}$ Intern. Symp. on Material Chemistry in Nuclear Environment (Japan Atomic Energy Research Institute, Tsukuba, Japan, 2003), p. 63.

14. A. I. Malkin, Colloid J., 74: 239 (2012).

15. V. V. Belousov, J.Am.Ceram.Soc., 79: 1703 (1996).

16. E. E. Glickman and M. Nathan, J.Appl. Phys., 85: 3185 (1999).

17. N. S. Stoloff, R. G. Davies, and T. L. Johnston, Environment-Sensitive Mechanical Behaviour (Eds. A. R. C. Westwood and N. S. Stoloff) (New York: Gordon and Breach: 1966), p. 613.

18. S. P. Lynch, Metal Sci., 15: 463 (1981).

19. M. H. Kamdar, Prog. Mater. Sci., 15: 289 (1973).

20. M. H. Kamdar, Advanced Research Strength and Fracture of Materials: Proc. $4^{\text {th }}$ Intern Conf Fract. (Canada: University of Waterloo: 1977), vol. 1, p. 387.

21. A. Kelly, W. R. Tyson, and A. H. Cottrell, Philos. Mag., 15: 567 (1967).

22. S. Ashok, N. S. Stoloff, M. E. Glicksman, and T. Slavin, Scr. Metall., 15: 331 (1981).

23. T. P. Slavin and N. S. Stoloff, Mat. Sci.Eng., 68: 55 (1984).

24. H. Nichols and W. Rostoker, Trans. AIME, 224: 1258 (1962).

25. P. C. Hancock and M. B. Ives, Canadian J. Metallurgy Mater. Sci., 10: 207 (1971).

26. M. M. Shea and N. S. Stoloff, Mater. Sci. Eng., 12: 245 (1973).

27. E. I. Rabkin, L. S. Shvindlerman, and B. V. Straumal, Intern. J. Modern. Phys. $B, 5: 2989$ (1991).

28. K. Tai, L. Feng, and Sh. J. Dillon, J. Appl. Phys., 113: 193507 (2013).

29. S. P. Lynch, Acta Metall., 32: 79 (1984).

30. S. P. Lynch, Acta Metall., 36: 2639 (1988).

31. S. P. Lynch, Metall. Mater. Trans. A, 44: 1209 (2013).

32. S. P. Linch, Cor. Rev., 30: 105 (2012).

33. V. G. Gavriljuk, B. D. Shanina, V. N. Shyvanyuk, and S. M. Teus, Cor. Rev., 31: 33 (2013).

34. W. S. Ryu, S. I. Hong, Y. Choi, Y. H. Kang, and C. S. Rim, J. Korean Nuclear Society, 17: 193 (1985).

35. P. Blaha, K. Schwarz, G. K. H. Madsen, D. Kvasnicka, and J. Luitz, WIEN2k, An Augmented Plane Wave+Local Orbitals Program for Calculating Crystal Properties (Wien, Austria: Techn. Universität Wien: 2001). 
36. P. Hohenberg and W. Kohn, Phys. Rev. B, 136: 864 (1964).

37. W. Kohn and L. J. Sham, Phys. Rev. A, 140: 1133 (1965).

38. M. Weinert, E. Wimmer and A. J. Freeman. Phys. Rev. B, 26: 4571 (1982).

39. J. P. Perdew, S. Burke, and M. Ernzernhoff, Phys. Rev. Lett., 77: 3865 (1996).

40. P. E. Blöchl, O. Jepsen, and O. K. Andersen, Phys. Rev. B, 49: 16223 (1994).

41. J. H. Pifer and R. T. Longo, Phys. Rev. B, 4: 3797 (1971).

42. G. Gavriljuk, S. P. Efimenko, Ye. E. Smuk, S. Yu. Smuk, B. D. Shanina, N. P. Baran, and V. M. Maksimenko, Phys. Rev. B, 48: 3224 (1993).

43. B. D. Shanina, V. G. Gavriljuk, S. P. Kolesnik, and V. N. Shivanyuk, J. Phys. D: Appl. Phys., 32: 298 (1999).

44. Y. Tsunoda, J. Phys.: Condensed Matter, 1: 10427 (1989).

45. E. Sjostedt and L. Nordstrom, Phys. Rev. B, 66: 014447 (2002).

46. I. A. Abrikosov, I. A. Kissavos, F. Liot, B. Alling, S. I. Simak, O. Peil, and A. V. Ruban, Phys. Rev. B, 76: 014434 (2007).

47. D. E. Jiang and E. Carter, Phys. Rev. B, 67: 214103 (2003).

48. H. C. Herper, E. Hoffmann, and P. Entel, Phys. Rev. B, 60: 3839 (1999).

49. M. Acet, H. Zaehres, E. F. Wassermann, and W. Pepperhoff, Phys. Rev. B, 49: 6012 (1994).

50. W. Keune, T. Ezawa, W. A. A. Macedo, U. Glos, K. P. Schletz, and U. Kirschbaum, Physica B, 161: 269 (1989).

51. C. Carbone, G. S. Sohal, E. Kisker, and E. F. Wassermann, J. Appl. Phys., 63: 3499 (1988).

52. A. Kokalj, J.Mol.Graph. Model., 17: 176 (1999).

53. G. Schoeck, E. Bisogni, and J. Shyne, Acta Metall., 12: 1466 (1964).

54. A. Rivière, V. Amirault, and J. Woirgard, Nuovo Cimento, 33: 398 (1976).

55. V. G. Gavriljuk, V. N. Shivanyuk, and J. Foct, Acta Mater., 51: 1293 (2003).

56. M. L. Martin, I. M. Robertson, and P. Sofronis, Acta Mater., 59: 3680 (2011).

57. Y. Tomota, Y. Xia, and K. Inoue, Acta Mater., 46: 1577 (1998).

58. R. B. McLellan, J.Phys. Chem. Sol., 49: 1213 (1988).

59. A. A. Smirnov, Reports of Academy of Sciences of UkrSSR, 7: 66 (1991).

60. Y. Fukai and N. Okuma, Jpn. J.Appl. Phys., 32: L1256 (1993).

61. V. G. Gavriljuk, V. N. Bugaev, Yu. N. Petrov, A. V. Tarasenko, and B. Z. Yanchitsky, Scr. Mater., 34: 903 (1996).

62. I. M. Robertson and H. K. Birnbaum, Acta Metal., 34: 353 (1986).

63. H. K. Birnbaum and P. Sofronis. Mater Sci. Eng. A, 176: 191 (1994).

64. P. Sofronis, Y. Liang, and N. Aravas, Eur. J. Mech. A/Solids, 20: 857 (2001).

65. I. M. Robertson, H. K. Birnbaum, and P. Sofronis, Dislocation in Solids. Ch. 91 (Eds. J. P. Hirth and L. Kubin) (New York: Elsevier: 2009), p. 250.

66. V. G. Gavriljuk, B. D. Shanina, V. N. Syvanyuk, and S. M. Teus, J. Appl. Phys., 108: 083723 (2010).

67. V. G. Gavriljuk, B. D. Shanina, V. N. Shyvanyuk, and S. M. Teus, Proceedings of the 2012 International Hydrogen Conference (September 9-12, 2012, Grand Teton National Park, Jackson Lake Lodge, Wyoming, USA) (Eds. B. P. Somerday and P. Sofronis) (New York: ASME Press: 2014), p. 67.

68. P. J. Ferreira, I. M. Robertson, and H. K. Birnbaum, Acta Mater., 46: 1749 (1998).

69. V. G. Gavriljuk, V. A. Duz', N. D. Aphanasyev et al., Corrosion-Resistant Austenitic Steel: Patent USSR No. 1507854 (15.05.1989).

70. A. L. Berezina, O. A. Molebny, and A. V. Kotko, Acta Phys. Polon. Series A, 128: 564 (2015). 